\title{
KRONIK
}

\section{Brug af borgeres data: En problematisering af etik som fundament for digital velfærd}

\author{
Brit Ross Winthereik
}

\section{Indledning}

I takt med at velfærdsprofessionelle forventes at arbejde tættere sammen med digitale teknologier, ændres også mulighedsbetingelserne for at udøve et fagligt skøn i kontakten med borgere. Som dette temanummer af Tidsskrift for Arbejdsliv viser, redistribueres ansvaret for udfaldet af kontakten på tværs af fagpersoner og teknologi når mennesker og maskiner samarbejder. Temanummeret er et velkomment bidrag til en længerevarende diskussion indenfor forskningsområderne offentlig administration og ledelse, kritiske teknologistudier, og om hvad der sker når styringsambitioner møder praksis (Vinge and Vikkelsø, 2004). Selvom meget er sagt og skrevet, er der fortsat behov for studier af hvordan arbejdslivet transformeres af den omsiggribende digitalisering af velfærdsprofessionerne.

Denne kronik forsøger at sætte temanummeret ind i en kontekst man kunne kalde 'digital velfærd med etik i ascendanten'. Der er for mig at se nemlig ingen tvivl om, at samfundsforskningens perspektiv på etik som situeret, relationel praksis bør spille en rolle i forhold til teknologiudvikling og implementering i velfærdsstaten. Kort fortalt rækker etik som praksis ud over den mini- male definition på etik, om ikke at skade andre. Den rækker også ud over spørgsmål om databeskyttelse og bias i IT-systemer og digitale platforme. Etik er i denne optik det at påtage sig normen om at reagere varieret $i$ mødet med specifikke anliggender, eller 'the capacity to respond to variability', (Zuiderent-Jerak, 2015: 190).

Politisk er der sket en bevægelse fra 2012 til i dag hvor data har fået en mere og mere fremtrædende rolle $i$ forhold til at sikre velfærden (KL, 2019). Dette politisk-strategiske fokus fører logisk til spørgsmålet om hvordan data indsamlet af de offentlige myndigheder så egentlig kan bruges, og hvad der skal til for at brugen foregår på en ansvarlig måde. I denne kronik vil jeg problematisere (Bacchi, 2012) ideen om etik som løsning på problemet om dataindsamling til mere velfærd og foreslå nogle fokusområder, som jeg mener er vigtige $\mathrm{i}$ forhold til ansvarlig digitalisering af den offentlige sektor.

\section{Digitalisering som eksperiment}

Når projektejere i offentlige digitaliseringsprojekter skal forklare befolkningen hvad de laver, bliver det ofte nævnt at 'vi lægger vejen mens vi går', eller 'vi bygger båden 
mens vi sejler'. Den slags metaforer peger på at digitalisering for det meste anskues som noget igangværende, men også i høj grad som noget eksperimentelt.

Ideen om digitalisering som eksperiment er knyttet til den evidens-baserede strømning i offentlig ledelse (Vohnsen, 2015; Rod and Jöhncke, 2014). Kort fortalt er det ideen om, at man kan skabe et sikkert grundlag for organisatoriske og ledelsesmæssige beslutninger. Selve begrebet evidens kommer fra naturvidenskaben og springer ud af videnskabeligt arbejde med kontrollerede laboratorieforsøg. Begrebets fortid ignoreres for det meste, og der er i mange offentlige myndigheder en stærk tro på, at man kan skabe et IT-miljø, der er kontrolleret nok til at opnå sikkerhed for beslutninger taget med brug af data. Men myndighederne har slet ikke IT infrastrukturer, der er stabile nok, og de sociale ting, der måles på, udvikler sig konstant. Det er derfor meget kompliceret at skabe evidens for organisatoriske beslutninger. Som en konsekvens heraf higer man efter nye systemer og mere data om borgerne. Dataindsamling bliver en uendelig proces, og tilsammen et næsten ukontrollabelt eksperiment (Hoeyer and Bødker, 2020).

Jeg mener ikke vi som samfund kan være tjent med en tilgang til digitalisering og dataindsamling, som både hævder at vi skal indsamle så meget som muligt om borgerne, men samtidig ikke har de lovmæssige rammer eller infrastrukturen på plads. Der er en intens debat i gang om hvilken fremtid vi ønsker os, i Danmark såvel som internationalt (Zuboff, 2019). I Danmark sætter etableringen af Dataetisk Råd fokus på spørgsmålet om hvilke rammer vi ønsker for Danmark. Måske er Dataetisk Råd et første skridt på vejen i at afgøre, hvor vi som digitaliseret samfund er på vej hen, og om vi går i den rigtige retning.

Men der er udfordringer. Det er nemlig slet ikke tilstrækkeligt at placere etik-diskussioner i råd. Især ikke når formålet med rådet ikke er funderet i egentlig (velfærds)praksis og samtidig tæt koblet til potentiale-tænkning, som det fremgår af formålsbeskrivelsen for Dataetisk Råd:

"Digitalisering og dataanvendelse rummer et
enormt potentiale for vaekst og innovation,
og giver mulighed for at udvikle nye tjene-
ster og produkter, der ikke tidligere er set. En
forudsaetning for at indfri dette potentiale er
imidlertid, at der i samfundet er tillid til, at
de nye teknologier og data anvendes på en
ansvarlig måde". (https://www.regeringen.
dk/media/4991/diskussionsoplã-g-data-
etik-pdf.pdf)

Når man lytter til politiske diskussioner om dataetik, lyder det af og til som om, at det at anlægge et etisk perspektiv på teknologi er noget ganske nyt. Det er det ikke. Vi bør ikke spørge, om vi skal tænke etikken ind i digitaliseringen, men spørge os selv om, hvorfor vi dog skulle holde op med at diskutere etik. Etisk Råd blev nedsat i forbindelse med at komplekse spørgsmål om kunstig befrugtning blev rejst. Spørgsmål der vedrørte selve betingelserne for det at være menneske. I næsten 40 år har den samfundsvidenskabelige teknologiforskning stillet spørgsmål til hvem vi er, og hvad vi bliver til som mennesker i vores omgang med teknologi (Callon, 1987; Callon and Rabeharisoa, 1999; Koch and Hoeyer, 2007). Så forholdet mellem etik og teknologi er slet ikke uberørt område, og vi ved allerede en masse. Blandt andet ved vi, at det etiske vedrører lovmæssige rammer, såvel som mere grundlæggende spørgsmål om hvordan, vi ønsker at leve sammen.

\section{To udfordringer}

Netop nu er der grund til at være særlig opmærksom på de etiske dimensioner af dataindsamling om borgere, brugen af digitale 
platforme, algoritmer og analysemetoder i velfærdsarbejde. Det skyldes flere ting, hvoraf jeg særligt vil fremhæve to. Den første vedrører de infrastrukturer, som transporterer og organiserer data, den anden vedrører selve dataindsamling og analyse.

Der er for det første nye private aktører på banen i den offentlige sektor, dem vi omtaler som tech-giganter. De har allerede nu et tæt samarbejde med kommunerne. Tech-giganterne søger skattemæssige fordele og muligheden for relativt usynligt men effektivt at etablere sig i forhold til mindst tre kerneområder i vores samfund: kritisk infrastruktur som energi- og varmeforsyning (fx etableringen af 9 datacentre i Danmark og Facebooks og Googles forhandling med fjernvarmeanlæg om at donere overskudsvarme fra de mange servere), læringsplatforme (fx tæt samarbejde med kommuner omkring fremtidens kompetencer for børn og unge) og i forhold til offentlig kommunikation generelt, hvor offentlige myndigheder benytter Facebook som platform for borgeroplysning og en stor del af samfundets politiske kommunikation foregår på sociale medier. Disse private aktører har ingen særlig interesse i det danske samfund eller den danske velfærdsmodel. Udover sikkerhedsaspektet er infrastrukturer bærere af kultur og værdier. Af den grund er spørgsmålet om ejerskab til kritisk infrastruktur et etisk spørgsmål: Dem, der har kontrollen over hvordan data transporteres og organiseres har også stor indflydelse på hvordan data indekseres og hvem, der i sidste ende har adgang til dem.

Jeg mener, der er behov for at løsrive sig fra tech-giganternes indflydelse på kritisk infrastruktur og kommunikationsinfrastrukturer, hvis ikke kan vi ende i en situation, hvor vi som nation ikke har mulighed for at tilgå eller træffe beslutninger omkring kritisk digitale infrastruktur. En mere ambitiøs tilgang kunne være at arbejdet med infrastruktur havde en inddragende og fælles- skabsfremmende dimension, hvor ejerskabet til de digitale rum, man samarbejder i er delt, tillige med ansvaret for at vedligeholde dem (commoning). ${ }^{1}$

En anden udfordring er, at vi - stadig - står med en overdreven tro på at digital optimering løser alt. Digitalisering i Danmark har indtil videre i stor udstrækning foregået topdown, og er blevet fulgt op af argumenter om bedre kvalitet og flere varme hænder fordi administrationsbyrden ville lettes. I praksis er det modsatte sket, og alle registrerer mere. Der er således et konstant behov for mere optimering når det, der skulle optimeres med digitaliseringen selv skal optimeres. Vi står et sted nu, hvor der er en overhængende risiko for at ødelægge teknologi, der fungerer godt i jagten på noget der er smartere. Det kan være svært, hvis ikke umuligt, at gennemskue hvordan 'gamle' teknologier og infrastrukturer ændrer sig, når nye digitale muligheder byder sig til. CPR-registret er fx en teknologi, der egentlig er skabt til at støtte op om, at alle borgere kan 'ses' lige tydeligt med henblik på at have de samme rettigheder uden dog at være helt transparente. Med nye digitale muligheder kan denne velfungerende teknologi blive omformet til også at være en overvågningsteknologi. Fx har ingen overblik over konsekvenserne af at lægge en gammel teknologi, sygesikringskortet, ind i en app.

Der er behov for at få et mere nuanceret blik på digitaliseringen, gevinster såvel som omkostninger og nye dilemmaer. Det kræver forskning og politik, der tør bevæge sig i grænselandet mellem det generelle og det konkrete, mellem idealer og hverdagens rod, og altid med et fokus på hvordan specifikke måder at gøre tingene på, forhandles når normer og værdier støder ind i hinanden.

\section{Hvad ved vi om etik?}

Det er ikke som sådan muligt at identificere 'det gode' som noget iboende samspillet 
mellem menneske og teknologi; både fordi 'det gode' kommer i mange versioner, kan være svært at sætte en finger på og løbende ændrer sig. Måske af den grund ser vi med digitaliseringens dilemmaer også udbredelsen af det man kan kalde 'revisionssamfundet', hvor etik kommer ind som lovgivning eller som tjeklister (fx GDPR) (Power, 1997). I lovgivningssammenhæng er 'det gode' oversat til det rette.

Som kontrast til tjeklisteetikken, som er binær og typisk vedrører regler og rammer, har vi relationel etik, som er situationsbestemt. Jarett Zigon, professor ved Center for Data Ethics and Justice ved University of Virginia, definerer relationel etik som det at kunne reagere situationsbestemt over for andre på en måde, der udviser et ansvar overfor den anden som et i princippet uendeligt ansvar, udstrakt i tid og rum. Kort sagt en respons, der rummer det, at "jeg kunne være i den andens sted og have brug for én som mig" (Zigon, 2020).

Den relationelle etik handler om: Hvordan er det mellem os (how is it between us?), hvordan er det at være i det mellemrum, hvor værdierne hele tiden forhandles og genforhandles? En projektleder, der skal implementere et nyt fagsystem i en kommune, ved, hvad de overordnede organisatoriske formål er, men er vedkommende klædt på til at respondere på dilemmaer af værdimæssig og etisk karakter, der konstant opstår i mødet mellem system, medarbejdere og ledelse?

\section{Etik i den kommunale forvaltning}

Indtil for nylig har etikken i mødet mellem stat og borger i høj grad været betinget af skønnet hos de fagpersoner, der mødte borgeren. Den situation er under hastig transformation, idet borgeren enten slet ikke møder et menneske, eller møder et, hvis faglige habitus og beslutningskraft er kraftigt formet af digitale teknologier. Det faglige skøn er sat under et voldsomt pres fx fra ønsket om brug af algoritmer i sagsbehandling.

Nyere studier peger på vigtigheden af fortsat at holde den etiske fane højt i relationen mellem myndighed og borger gennem kritisk refleksion over gangbarheden af digitale løsninger på 'gulvet' og hos ledelsen (Petersen et al., 2020; Justesen and Plesner, 2018). Etikken vedrører her både udformningen af de teknologier og infrastrukturer, som kommunale medarbejdere skal samarbejde med og vedrører spørgsmålet om hvorvidt borgernes data er beskyttet i tilstrækkelig grad, om der er givet samtykke og om samtykket nemt kan trækkes tilbage, og hvem der har ejerskab til infrastrukturer og de data, de transporterer.

Spørgsmålet om hvad der sættes i stedet for det faglige skøn er også et spørgsmål om hvorvidt sagsbehandleren er i stand til at samarbejde med et system, der er sat i verden for at overflødiggøre eller udgrænse den situerede menneskelige beslutningstagning. Afledt heraf kan det blive sværere for borgeren at finde mening i myndighedsbeslutninger, hvis sagsbehandleren ikke er i stand til at forklare algoritmens rolle? ${ }^{2}$ Når jeg taler med ledere i den offentlige sektor, bider jeg mærke i, at de føler, de er underlagt et pres for at 'eksperimentere til kanten af loven'. Det er for mig at se kritisk, hvis offentlige myndigheder tvinges ud i at ignorere deres (egen) faglige ethos i forhold til om det de laver er etisk forsvarligt eller ej.

En leder beskrev den datadrevne kommune som 'det vilde vesten'. Det hænger måske sammen med at den datadrevne kommune rummer forventningen om, at data på en gang kan udnyttes og udforskes. Det er svært at vurdere om en løsning vil være uetisk i praksis - øjnene er fast rettet på målet om at sætte data i spil og på vejen derhen fremfor at komme frem i et stykke. Det er et udbredt problem, at rammerne er for vage. Måske skyldes det at mange kommuner vil det hele på en gang - apps til hjemløse, AI 
i sagsbehandling, robotter i ældreplejen og datadrevet ledelse. Det kræver et bredt udsyn, men også konkrete mål og detaljeret opfølgning at kunne udføre tjeklisteetik og samtidig forestille sig hvordan en teknologi vil komme til at virke i bestemte situationer i fremtiden. Her mener jeg professionsforskning og kritisk samfundsvidenskabelig forskning i digital velfærd kan bidrage.

\section{Afrunding}

Mennesker i velfærdsprofessioner forventes at deltage i det igangværende eksperiment med digitalisering $\mathrm{i} /$ af den offentlige sektor. Hidtil har betydningen af eksperimentet for ledere og politikere været italesat som den si- tuation 'at fremtiden er åben', vi lægger vejen mens vi går. Der er behov for at få italesat en anden betydning af en eksperimentel etos, som er at sætte rammen for at deltagerne i eksperimentet kan tage ansvar for det, de er i færd med. Forståelse for situeret etisk praksis eller relationel etik kan være et skridt på vejen. Det handler ikke kun om at bygge bro mellem idealerne om at gøre 'det rette' og at kunne reagere på konkrete problemstillinger i praksis. Det handler i ligeså høj grad om at forstå at digitaliseringen konstant forsyner os med nye dilemmaer af etisk-politisk karakter, som ikke vil kunne løses en gang for alle, og derfor kræver at dem, der eksperimenterer også påtager sig ansvaret for eksperimenternes udfald.

\section{REFERENCER}

Bacchi C (2012) Why study problematizations: Making politics visible. Open Journal of Political Science 2(2): 1-8.

Callon M (1987) Society in the making: The study of technology as a tool for sociological analysis In: Huges T and Pinch $\mathrm{T}$ (eds) The social construction of technological systems: New directions in the sociology and history of technology London: MIT Press, pp.83-103.

Callon M and Rabeharisoa V (1999) Gino's Lesson on Humanity. Producing Taste, Configuring Use, Performing Citizenship. Maastricht.

Hoeyer K and Bødker M (2020) Weak Data: The Social Biography of a Measurement Instrument and How It Failed to Ensure Accountability in Home Care. Medical Anthropology Quarterly 34(3): 420-437.

Justesen L and Plesner U (2018) Fra skøn til algoritme: Digitaliseringsklar lovgivning og automatisering af administrativ sagsbehandling. Tidsskrift for Arbejdsliv 20(3): 9-23.

KL (2019) På forkant med fremtidens velfærd: Strategi for KL's arbejde med digitalisering, ny teknologi og data. Reportno. Report Number|, Date. Place Published|: Institution|.

Koch L and Hoeyer K (2007) Håbets teknologi: Samfundsvidenskabelige perspektiver på stamcelleforskning i Danmark. København: Munksgaard.

Petersen ACM, Christensen LR and Hildebrandt TT (2020) The Role of Discretion in the Age of Automation. Computer Supported Cooperative Work.

Power M (1997) The Audit Society: Rituals of Verification. Oxford: Clarendon Press.

Rod M and Jöhncke S (2014) The social life of evidence: rationalizing professional practice in the welfare state Critical Anthropology 4: 41-68.

Vinge S and Vikkelsø S (2004) Hverdagens arbejde og organisering $i$ sundhedsvoesenet. København: Handelshøjskolens Forlag.

Vohnsen NH (2015) Evidensbaseret politikudvikling: Brudflader mellem forskning og bureaukrati. Tidskriftet Antropologi 72: 39-60.

Zigon J (2020) Can Machines Be Ethical? On the Necessity of Relational Ethics and Empathic Attunement for Data-Centric Technologies. Social Research: An International Quarterly 86(4): 1001-1022. 
Zuboff S (2019) The age of surveillance capitalism: the fight for a human future at the new frontier of power. New York: PublicAffairs.
Zuiderent-Jerak T (2015) Situated intervention : sociological experiment in health care. Cambridge, Massachusetts: The MIT Press.

\section{Noter}

1 Joanna Saad-Sulonen og kollegaer arbejder med dette begreb i kontekst af Center for Digital Velfærds gruppe Democratic Digital Spaces. Se https://cdw.itu.dk/about.

2 Se også Jørgensen, B., C. Gad, B.R. Winthereik. (under udgivelse). "Organizing Artificial Intelligence", In: Pink, S. and Waltorp, K. Contested Technologies: Future Anthropologies. Bloomsbury om behovet for transparente algoritmer i SKAT.

Brit Ross Winthereik, professor

Center for Digital Velfærd, IT Universitetet i København

e-mail: brwi@itu.dk 